\title{
36. DATA REPORT: GEOCHEMICAL LOGGING THROUGH AN ACCRETIONARY PRISM: CHILE TRIPLE JUNCTION ${ }^{1}$
}

\author{
Elizabeth Lewis Pratson, ${ }^{2}$ Cristina Broglia, ${ }^{2}$ Xenia Golovchenko, ${ }^{2}$ Amane Waseda, ${ }^{3}$ and Philip Froelich ${ }^{4}$
}

\begin{abstract}
Geochemical well logs were obtained through sediments at Leg 141 Sites 859 and 863 . Corrections have been applied to the logs to account for variations in borehole size, drilling-fluid composition, and drill-pipe attenuation. Concentrations of Th, U, and $\mathrm{Gd}$, as well as oxide weight percentages, have been calculated from the logs and compared with shipboard and shorebased $\mathrm{X}$-ray-fluorescence (XRF) and carbonate bomb core measurements. The geochemical processing was performed in both open hole and cased sections of Holes $859 \mathrm{~B}$ and $863 \mathrm{~B}$. Comparison of XRF core data to log data is good.
\end{abstract}

\section{INTRODUCTION}

During Leg 141, two sites were drilled into the toe of the accretionary prism at the point where the Chile Ridge is about to be (Site 859 ), or has already been (Site 863), subducted. The purposes of drilling these sites were to determine the lithologies, depositional environments of the sediments, and the extent of hydrothermal alteration (Shipboard Scientific Party, 1992a, 1992b). To provide a continuous determination of lithology, Holes $859 \mathrm{~B}$ and $863 \mathrm{~B}$ were logged with the geochemical logging tool string (GLT), which measures the major elements of a formation at intervals of $0.15 \mathrm{~m}$. The GLT measurements provide continuous, in-situ chemical measurements of the rock and are not affected by incomplete core recovery or core expansion, a common problem in core-based studies.

This report describes the basic principles of the GLT and outlines the post-cruise processing techniques. It then briefly compares geochemical log values with lithologic core descriptions and available core measurements.

\section{GEOCHEMICAL TOOL STRING}

The geochemical logging tool string consists of four tool components: the natural gamma-ray tool (NGT), the compensated neutron tool (CNT), the aluminum activation clay tool (AACT), and the gamma-ray spectrometry tool (GST). (GLT, NGT, CNT, AACT, and GST are trademarks of Schlumberger; Fig. 1.) The combination of the tool components uses three separate modes of gamma-ray spectroscopy for a comprehensive elemental analysis of the formation. The NGT, located at the top of the tool string, measures the naturally occurring radionuclides thorium (Th), uranium (U), and potassium (K) before the formation is irradiated by the nuclear sources contained in the tools below. The CNT, located below the NGT, carries a low-energy californium-252 $\left({ }^{252} \mathrm{Cf}\right)$ neutron source to activate the $\mathrm{Al}$ atoms in the formation. The AACT, a modified NGT, is located below the ${ }^{252} \mathrm{Cf}$ source, measuring the activated gamma rays in the formation. By combining the AACT measurement with the previous NGT measurement, the background radiation is eliminated, and a reading of formation $\mathrm{Al}$

\footnotetext{
${ }^{1}$ Lewis, S.D., Behrmann, J.H., Musgrave, R.J., and Cande, S.C. (Eds.), 1995. Proc. $O D P$, Sci. Results, 141: College Station, TX (Ocean Drilling Program).

${ }^{2}$ Borehole Research Group, Lamont-Doherty Earth Observatory, Columbia University, Palisades, NY 10964, U.S.A.

${ }^{3}$ JAPEX Research Center, 1-2-1 Hamada, Mihama-ku, Chiba 261, Japan.

${ }^{4}$ Lamont-Doherty Earth Observatory and Department of Geological Sciences, Columbia University. Palisades, NY 10964, U.S.A.
}

is obtained (Scott and Smith, 1973). The GST, at the base of the string, carries a pulsed neutron generator to induce prompt-capture gammaray reactions in the borehole and formation and an $\mathrm{NaI}(\mathrm{Tl})$ scintillation detector to measure the energy spectrum of gamma rays generated by the neutron-capture reactions. Because each of the elements in the formation is characterized by a unique spectral signature, it is possible to derive the contribution (or yield) of each of the major elements silicon $(\mathrm{Si})$, iron $(\mathrm{Fe})$, calcium $(\mathrm{Ca})$, titanium $(\mathrm{Ti})$, sulfur $(\mathrm{S})$, gadolinium (Gd), and potassium (K) from the measured spectrum. By combining these yields with the elemental concentrations from the NGT and AACT one can estimate the relative abundance in the formation of each element above. The GST also measures the hydrogen $(\mathrm{H})$ and chlorine $(\mathrm{Cl})$ in the borehole and formation, but these elements are not used for determining rock geochemistry.

The only major rock-forming elements not measured by the GST are magnesium $(\mathrm{Mg})$ and sodium $(\mathrm{Na})$; the neutron-capture cross sections of these elements are too small relative to their typical abundance to be detected by the GST. A rough estimate of $\mathrm{Mg}+\mathrm{Na}$ can be made by using the photoelectric factor (PEF), measured by the lithodensity tool. This measured PEF is compared with a calculated PEF (a summation of the PEF from all of the measured elements). The separation between the measured and calculated PEF is, in theory, attributable to any element left over in the formation (i.e., $\mathrm{Mg}$ and Na). Further explanation of this technique is found in Hertzog et al. (1989). The $\mathrm{Mg}$ calculation was not attempted for this leg, because including it in the normalization with the other elements induced noise into all other elements, this problem is pervasive for ODP geochemical logs (Pratson et al., 1993). $\mathrm{MgO}+\mathrm{Na}_{2} \mathrm{O}+\mathrm{MnO}$ values from core data are included in the normalization step of the processing. This is explained further in Step 5 of the data-reduction section below.

\section{DATA REDUCTION}

The well-log data from the Schlumberger tools are transmitted digitally up a wireline and are recorded and processed on the JOIDES Resolution in the Schlumberger Cyber Service Unit (CSU). The results from the CSU are made available as "field logs" for initial, shipboard interpretation. Subsequent reprocessing is necessary to correct the data for the effects of fluids added to the well, logging speed, and drill-pipe interference. Processing of the spectrometry data is required to transform the relative elemental yields into oxide weight fractions.

The processing is performed with a set of log-interpretation programs written by Schlumberger, which were modified to account for the lithologies and hole conditions encountered in ODP holes. The steps are summarized in Figure 2 and described in more detail below: 
TCCB

\section{NGT}

NGT

CNT-G

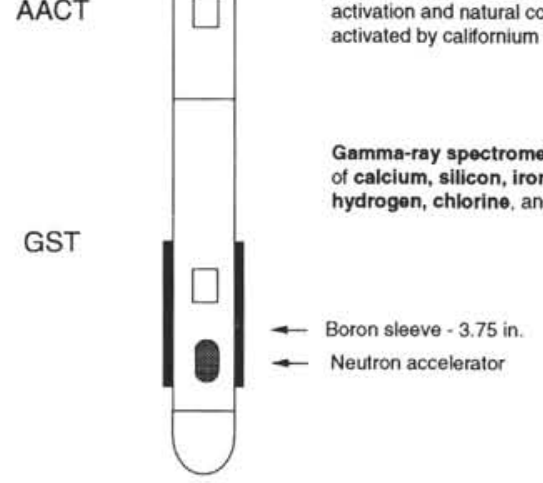

Figure 1. Schematic drawing of the Schlumberger geochemical logging tool string used in the Ocean Drilling Program.

\section{Reconstruction of Relative Elemental Yields from Recorded Spectral Data}

This first processing step compares the measured spectra from the gamma-ray spectrometry tool with a series of "standard" spectra to determine the relative contribution (or yield) of each element. Each "standard" approximates the spectrum of each element and is combined at each depth with the recorded spectrum in a weighted, leastsquares inversion to determine the relative elemental yields.

Six elemental standards ( $\mathrm{Si}, \mathrm{Fe}, \mathrm{Ca}, \mathrm{S}, \mathrm{Cl}$, and $\mathrm{H}$ ) are used to produce the shipboard yields, but three additional standards ( $\mathrm{Ti}, \mathrm{Gd}$, and $\mathrm{K}$ ) can be included in the post-cruise processing to improve the fit of the spectral standards to the measured spectra (Grau and Schweitzer, 1989). Although $\mathrm{Ti}, \mathrm{Gd}$, and $\mathrm{K}$ often appear in the formation in very low concentrations, they can make a large contribution to the measured spectra because they have large neutron-capture cross sections. For example, the capture cross section of Gd is 49,000 barns, whereas that of $\mathrm{Si}$ is 0.16 barns (Hertzog et al., 1989). Therefore, including Gd is necessary when calculating the best fit of the standard spectra to the measured spectra.

The spectral analysis was performed using the spectral standards for $\mathrm{H}, \mathrm{Si}, \mathrm{Ca}, \mathrm{Cl}, \mathrm{Fe}, \mathrm{Ti}, \mathrm{S}$, and $\mathrm{Gd}$. The spectral standards for $\mathrm{K}$ was not used, because this element exist in concentrations below the resolution of the tool, and the inclusion of $\mathrm{K}$ was found to significantly increase the noise level of all the other yields. A straight, five-point $(2.5 \mathrm{ft}, 0.762 \mathrm{~m})$ smoothing filter was applied to all the yields to reduce the noise in the data during this reconstruction step. An additional 10 point $(7 \mathrm{ft}, 2.13 \mathrm{~m}$ ) smoothing filter was applied to the yields to further reduce the noise level in the normalization factor (explained in step 5), which affects the overall character of the final elemental yields.

\section{Depth Shifting}

Geochemical processing involves the integration of data from the different tool strings; consequently, it is important that all the data are depth correlated to one reference logging run. The NGT, run on each of the logging tool strings, provides a spectral gamma-ray curve with which to correlate each of the logging runs. A reference run is chosen on the basis of low cable tension (the logging run with the least amount of tool sticking) and high cable speed (tools run at faster speeds are less likely to stick and are less susceptible to data degradation caused by ship heave). The depth-shifting procedure involves selecting several reference points where log characters are similar and then utilizing a program that stretches or squeezes sections of the matching logging run to fit the reference logging run. The geochemical tool string was the reference logging run for Hole $859 \mathrm{~B}$; the third pass of the Formation MicroScanner tool string was the reference run for Hole 863B.

\section{Calculation of Total Radioactivity and Th, U, and $\mathrm{K}$ Concentrations}

The third processing routine calculates the total natural gamma radiation in the formation as well as concentrations of $\mathrm{Th}, \mathrm{U}$, and $\mathrm{K}$, using the counts in five spectral windows from the natural gamma-ray tool (Lock and Hoyer, 1971). This routine resembles shipboard processing; however, the results are improved during post-cruise processing by including corrections for hole-size changes and temperature variations. A Kalman filtering (Ruckebusch, 1983) is used in the CSU processing at sea to minimize the statistical uncertainties in the logs, which can otherwise create erroneous negative values and anti- correlation (especially between Th and U). An alpha filter has been introduced more recently and is now recommended by Schlumberger for shore-based processing. This filter strongly smooths the raw spectral counts but keeps the total gamma-ray curve unsmoothed before calculating the Th, $\mathrm{U}$, and $\mathrm{K}$ (Charles Flaum, pers. comm., 1988). The outputs of this program are K (wet wt\%), U (ppm), and Th (ppm), as well as total gamma-ray and computed gamma-ray (total gamma ray minus $\mathrm{U}$ contribution) curves.

\section{Calculation of Al Concentration}

The fourth processing routine calculates the concentration of $\mathrm{Al}$ in the formation using four energy windows recorded with the AACT. During this step, corrections are made for natural radioactivity, borehole-fluid neutron-capture cross section, formation neutron-capture cross section, formation slowing-down length, and borehole size. Porosity and density logs are needed to convert the wet-weight percentages of $\mathrm{K}$ and $\mathrm{Al}$ curves to dry-weight percentages. The neutron porosity curve was used in both Holes $859 \mathrm{~B}$ and $863 \mathrm{~B}$. In Hole $859 \mathrm{~B}$, this curve had to be rescaled to match cores using the formula:

$$
\emptyset_{t}=\left(\rho_{n}-35\right) \times 0.54,
$$

where:

$\emptyset \mathrm{t}=$ percentage porosity, and $\rho_{n}=$ neutron density.

The reason for this large rescaling of porosity is the fact that the neutron source in this tool is a ${ }^{252} \mathrm{Cf}$, instead of an AmericiumBeryllium (AmBe) source which the tool was originally calibrated for.

$\mathrm{A}$ correction is also made for $\mathrm{Si}$ interference with $\mathrm{Al}$; the ${ }^{252} \mathrm{Cf}$ source activates the $\mathrm{Si}$, producing the aluminum isotope ${ }^{28} \mathrm{Al}$ (Hertzog et al., 1989). The program uses the $\mathrm{Si}$ yield from the gamma-ray 


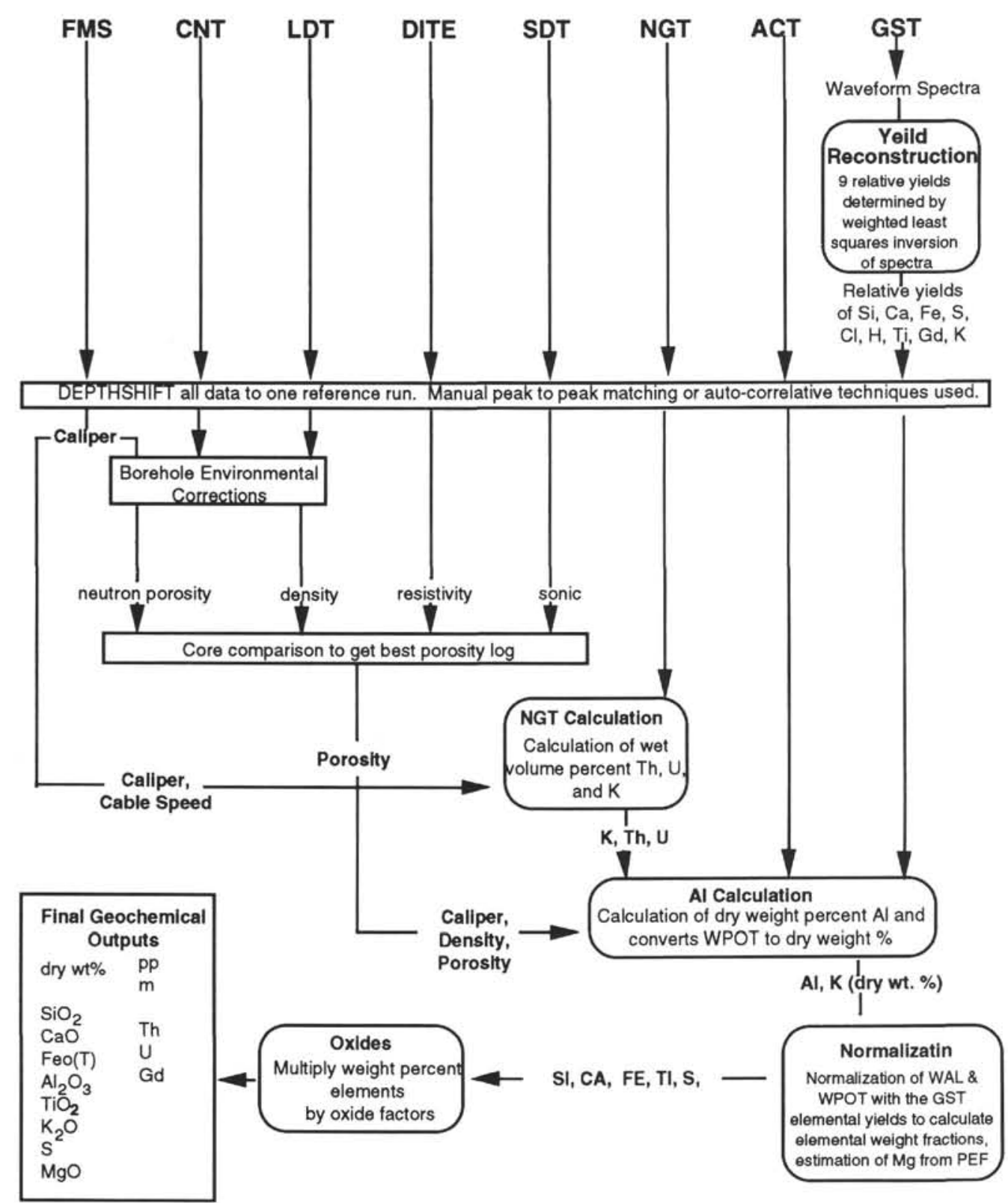

Figure 2. Flow chart of the processing steps involved in arriving at final oxides from raw geochemical logs.

spectrometry tool to determine the Si background correction. The program calculates dry-weight percentages of $\mathrm{Al}$ and $\mathrm{K}$, which are used in the calculation and normalization of the remaining elements.

\section{Normalization of Elemental Yields from the GST to Calculate Elemental Weight Fractions}

Relative concentrations of the GST-derived elemental yields can be determined by dividing each elemental yield by a relative spectral sensitivity factor $S_{i}$. These factors are constants, which can be measured in the laboratory and are principally related to the thermal neutron-capture cross sections and the gamma-ray production and detection probabilities of the element (Hertzog et al., 1989). The relative elemental concentrations are related to the desired absolute concentrations by a depth-dependent normalization factor $F$, as defined by the relationship:

$$
W t_{i}=F Y_{i} / S_{i} \text {, }
$$

where:

$W t_{i}=$ absolute elemental concentration, $Y_{i}=$ relative elemental yield, $S_{i}=$ relative spectral sensitivity factor, and $F=$ depth-dependent normalization factor.

The normalization factor is calculated on the basis that the sum of the elemental weight fractions is $100 \%$. The closure model accounts for carbon and oxygen, which are not measured by this tool string, by approximating their amounts in combination with each of the measurable elements as a single carbonate or oxide factor. The dry-weight percentages of $\mathrm{Al}$ and $\mathrm{K}$ are normalized with the reconstructed elemental yields to determine $F$ at each depth interval with the following equation:

$$
F\left(\Sigma_{i} X_{i} Y_{f} / S_{i}\right)+X_{K} W t_{K}+X_{A l} W t_{A l}=100,
$$

where:

$X_{i}=$ oxide factor: atomic wt of oxide or carbonate $\div$ atomic wt of element $i ; X_{K}=$ oxide factor of $\mathrm{K}$ : atomic wt of oxide of element $\mathrm{K} \div$ 
Table 1. Oxide factors used in normalizing elements to $100 \%$ and converting elements to oxides.

\begin{tabular}{lll}
\hline \multicolumn{1}{c}{ Element } & Oxide/carbonate & Conversion factor \\
\hline $\mathrm{Si}$ & $\mathrm{SiO}_{2}$ & 2.139 \\
$\mathrm{Ca}<6 \%$ & $\mathrm{CaO}$ & 1.399 \\
$6 \%>\mathrm{Ca}<12 \%$ & $\mathrm{CaO}$ and $\mathrm{CaCO}_{3}$ & $1.399-2.490 *$ \\
$\mathrm{Ca}>12 \%$ & $\mathrm{CaCO}_{3}$ & 2.490 \\
$\mathrm{Fe}$ & $\mathrm{Fe}_{2} \mathrm{O}_{3}$ & 1.430 \\
$\mathrm{~K}$ & $\mathrm{~K}_{2} \mathrm{O}^{2}$ & 1.205 \\
$\mathrm{Ti}$ & $\mathrm{TiO}_{2}$ & 1.668 \\
$\mathrm{Al}$ & $\mathrm{Al}_{2} \mathrm{O}_{3}$ & 1.889 \\
\hline
\end{tabular}

Note: $\left(^{*}\right)=$ linearly interpolated

atomic wt of $\mathrm{K} ; W t_{K}=$ dry-weight $\%$ of $\mathrm{K}$ measured from NGT; $X_{A l}$ $=$ oxide factor of $\mathrm{Al}$ : atomic wt of oxide of element $\mathrm{Al} \div$ atomic wt of $\mathrm{Al}$, and $W t_{A l}=$ dry-weight $\%$ of $\mathrm{Al}$ measured from the AACT.

The value $X_{i}$ accounts for the $\mathrm{C}$ and $\mathrm{O}$ associated with each element. Table 1 lists the oxide factors used in this calculation. All the measured elements associate with $\mathrm{C}$ and $\mathrm{O}$ in a constant ratio in these lithologies, except for $\mathrm{Ca}$, which associates with $\mathrm{C}$ and $\mathrm{O}$ in one of two ways: $\mathrm{CaCO}_{3}$ or $\mathrm{CaO}$ (Table 1). To convert the measured yields to elements, a dominant oxide factor must be assumed at each depth level. A routine that combines both these oxide factors is implemented here, as suggested by Jim Grau at Schlumberger-Doll Research (pers. comm., 1992). When the elemental form of $\mathrm{Ca}$ is less than $6 \%, \mathrm{CaO}$ is assumed, and an oxide factor of 1.39 is used. When the elemental form of $\mathrm{Ca}$ is greater than $12 \%, \mathrm{CaCO}_{3}$ is assumed, and an oxide factor of 2.49 is used. When the elemental form of $\mathrm{Ca}$ is between $6 \%$ and $12 \%$, both forms are assumed to be present, and the oxide factor is linearly interpolated between 1.39 and 2.49 .

The parameters $6 \%$ and $12 \%$ were chosen according to observations of how $\mathrm{Ca}$ occurs in nature. $\mathrm{CaO}$ is not likely to occur in quantities greater than $12 \%$, therefor $\mathrm{CaCO}_{3}$ is a logical assumption in these instances. When $\mathrm{Ca}$ is less than $6 \%$, even if $\mathrm{CaCO}_{3}$ was incorrectly assumed, the error would be very small when 1.39 is used as the oxide factor instead of 2.49. The linear interpolation is done in order to provide a smooth transition and avoid invoking any erroneous character changes on the final processed logs. This procedure for $\mathrm{Ca}$ gives the best model in most cases and minimizes the error when the model is not exactly correct.

The Mg- and Na-content curves cannot be calculated from the logs, because the neutron-capture cross sections of these elements are too small relative to their typical abundance for detection by the tool string; therefore, available core information is included. A constant value of $6.38 \% \mathrm{MgO}+\mathrm{Na}_{2} \mathrm{O}+\mathrm{MnO}$ was used in the normalization of Hole $863 \mathrm{~B}$. This value was derived from the average measured core values. No renormalization was performed in Hole $859 \mathrm{~B}$ to account for these oxides, due to lack of representative XRF data at the time of processing.

\section{Calculation of Oxide Percentages}

The final routine converts the elemental weight percentages into oxide/carbonate percentages by multiplying each by its associated oxide factor, as shown in Table 1.

\section{Calculation of Error Logs}

The calculated statistical uncertainty of each element is calculated from each of the elements measured with the GST and NGT (Grau et al., 1990; Schweitzer et al., 1988). This error is strongly related to the normalization factor, which is calculated at each depth (Equation 2). The normalization factor is displayed to the right of the oxide logs. A lower normalization factor represents better counting statistics and higher quality data.

\section{COMPARISON OF GEOCHEMICAL LOGS WITH CORES FROM HOLES 859B AND 863B}

\section{Site 859}

The processed natural gamma-ray curves for Hole 859B, shown in Figure 3, are displayed adjacent to core-recovery and lithostratigraphic columns. The processed NGT curves are from the geochemical logging tool string. Figure 4 displays the oxide-weight fractions estimated from the logs from Hole $859 \mathrm{~B}$, along with calculated statistical uncertainties of each element (Grau et al., 1990; Schweitzer et al., 1988). Core measurements of XRF major elemental analyses are displayed as solid circles for comparison with the oxideweight fractions derived from the log data. XRF data are listed in Table 2, representing both shipboard and shore-based data.

The sediments at Site 859 are composed of fine-grained terrigenous clastic material (dominated by glacial rock flour) derived from the adjacent continental (Andean) volcanic arc and crystalline basement. Both the elemental logging data and the XRF data reflect this compositionally homogeneous detrital source.

Table 2. Shipboard and shore-based XRF analyses, Site 859.

\begin{tabular}{|c|c|c|c|c|c|c|c|c|c|c|c|}
\hline Source & Hole & Core & Section & $\begin{array}{l}\text { Depth } \\
\text { (mbsf) }\end{array}$ & $\mathrm{SiO}_{2}$ & $\mathrm{CaO}$ & $\mathrm{Fe}_{2} \mathrm{O}_{3}$ & $\mathrm{Al}_{2} \mathrm{O}_{3}$ & $\mathrm{MgO}^{*}$ & $\mathrm{~K}_{2} \mathrm{O}$ & $\mathrm{TiO}_{2}$ \\
\hline Shore & $859 \mathrm{~A}$ & $\mathrm{IH}$ & 1 & 0.05 & 57.75 & 5.09 & 5.89 & 13.72 & 6.40 & 1.75 & 0.84 \\
\hline Shore & $859 \mathrm{~A}$ & $2 \mathrm{H}$ & i & 2.68 & 56.40 & 4.51 & 7.34 & 15.50 & 7.09 & 2.11 & 0.95 \\
\hline Shore & $859 \mathrm{~A}$ & $4 \mathrm{H}$ & 4 & 21.61 & 59.87 & $4.7 i$ & 6.79 & 15.66 & 7.23 & 1.94 & 0.90 \\
\hline Shore & $859 \mathrm{~A}$ & $6 x$ & 2 & 36,45 & 61.60 & 4.79 & 5.89 & 14.63 & 9.16 & 1.71 & 0.86 \\
\hline Ship & $859 \mathrm{~B}$ & $\mathrm{IR}$ & $\frac{2}{2}$ & 53.94 & 60.63 & 4.74 & 7.35 & 16.89 & 3.72 & 2.05 & 0.88 \\
\hline Shore & $859 \mathrm{~B}$ & IR & 2 & 54.01 & 57.98 & 4.43 & 7.35 & 16.03 & 6.79 & 2.14 & 0.94 \\
\hline Shore & $859 \mathrm{~B}$ & $4 \mathrm{R}$ & i & 58.50 & 58.50 & 5.57 & 7.32 & 16.08 & 11.10 & 1.76 & 1.05 \\
\hline Ship & $859 \mathrm{~A}$ & iix & 3 & 71.90 & 58.54 & 3.43 & 7.56 & 18.31 & 3.83 & 2.79 & 0.86 \\
\hline Shore & $859 \mathrm{~A}$ & $13 \hat{x}$ & $i$ & 78.10 & 58.94 & 3.41 & 7.31 & 16.68 & 9.57 & 2.58 & 0.96 \\
\hline Ship & $859 \mathrm{~A}$ & $4 \hat{X}$ & 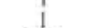 & 87.91 & 60.69 & 3.45 & 739 & 18.07 & 6.29 & 2.79 & 0.82 \\
\hline Ship & $859 \mathrm{~A}$ & $20 \mathrm{x}$ & $\mathrm{CC}$ & 136.16 & 60.30 & 3.81 & 8.63 & 18.39 & 7.16 & 2.66 & 0.95 \\
\hline Ship & $859 \mathrm{~B}$ & IOR & 5 & 203.22 & 58.75 & 4.35 & 7.74 & 17.84 & 3.90 & 2.34 & 0.88 \\
\hline Shore & $859 \mathrm{~B}$ & IIR & i & 206.94 & 63.05 & 2.57 & 6.29 & 15.74 & 5.69 & 2.40 & 0.86 \\
\hline Shore & $859 \mathrm{~B}$ & $\mathrm{I} 4 \mathrm{R}$ & 3 & 238.70 & 55.86 & 4.89 & 7.16 & 15.33 & 7.47 & 2.18 & 1.01 \\
\hline Shore & $859 \mathrm{~B}$ & $19 \mathrm{R}$ & 3 & 287.12 & 57.87 & 4.81 & 7.01 & 15.07 & 10.70 & 1.66 & 0.92 \\
\hline Ship & $859 \mathrm{~B}$ & $19 \mathrm{R}$ & 4 & 289.22 & 58.49 & 4.35 & 7.89 & 17.19 & 4.41 & 2.35 & 0.84 \\
\hline Shore & $859 \mathrm{~B}$ & $2 \mathbb{R}$ & 3 & 306.16 & 57.98 & 5.11 & 7.15 & 15.46 & 7.98 & 1.63 & 0.98 \\
\hline Shore & $859 \mathrm{~B}$ & $22 \mathrm{R}$ & i & 313.26 & 57.32 & 4.66 & 7.46 & 15.71 & 7.76 & 1.93 & 0.93 \\
\hline Shore & $859 \mathrm{~B}$ & $25 R$ & 4 & 346.80 & 60.91 & 2.68 & 7.08 & 16.47 & 9.81 & 2.67 & 0.94 \\
\hline Ship & $859 \mathrm{~B}$ & $29 \mathrm{R}$ & 2 & 381.57 & 60.71 & 5.87 & 7.58 & 16.67 & 4.09 & 1.23 & 0.92 \\
\hline Ship & $859 \mathrm{~B}$ & $36 \mathrm{R}$ & i & 381.57 & 64.77 & 2.10 & 5.47 & 15.07 & 2.73 & 2.56 & 0.65 \\
\hline Shore & $859 \mathrm{~B}$ & $30 R$ & 4 & 394.50 & 60.38 & 2.95 & 6.72 & 16.02 & 6.33 & 2.68 & 0.87 \\
\hline Shore & $859 \mathrm{~B}$ & $33 \mathrm{R}$ & $i$ & 418.92 & 66.81 & $1.7 i$ & 5.46 & 15.29 & 8.04 & 2.60 & 0.77 \\
\hline Shore & $859 \mathrm{~B}$ & $38 \mathrm{R}$ & i & 467.58 & 62.34 & 2.13 & 6.35 & 16.07 & 5.47 & 2.96 & 0.87 \\
\hline
\end{tabular}

Notes: The shore-based analyses were done by Amane Waseda. $\mathrm{MgO}^{*}$ represents the combination of $\mathrm{MgO}+\mathrm{Na} 2 \mathrm{O}+$ $\mathrm{MnO}$. 
Table 3. Shipboard and shore-based XRF analyses, Site 863.

\begin{tabular}{|c|c|c|c|c|c|c|c|c|c|c|c|}
\hline Source & Hole & Core & Section & $\begin{array}{l}\text { Depth } \\
\text { (mbsf) }\end{array}$ & $\mathrm{SiO}_{2}$ & $\mathrm{CaO}$ & $\mathrm{Fe}_{2} \mathrm{O}_{3}$ & $\mathrm{Al}_{2} \mathrm{O}_{3}$ & $\mathrm{MgO}^{*}$ & $\mathrm{~K}_{2} \mathrm{O}$ & $\mathrm{TiO}_{2}$ \\
\hline Shore & $863 \mathrm{~A}$ & $\mathrm{IH}$ & 4 & 5.33 & 59.63 & 4.48 & 6.74 & 15.30 & 7.27 & 2.04 & 0.94 \\
\hline Shore & $863 \mathrm{~A}$ & $5 \mathrm{H}$ & 1 & 37.82 & 58.69 & 3.73 & 7.19 & 15.08 & 6.24 & 2.42 & 0.90 \\
\hline Ship & $863 \mathrm{~A}$ & $5 \mathrm{H}$ & 2 & 39.70 & 61.69 & 3.21 & 6.92 & 17.52 & 6.33 & 2.93 & 0.80 \\
\hline Shore & $863 \mathrm{~A}$ & $7 \mathrm{X}$ & i & 56.46 & 58.94 & 3.54 & 6.65 & 15.34 & 6.43 & 2.89 & 0.92 \\
\hline Ship & $863 \mathrm{~A}$ & $9 \hat{\mathrm{X}}$ & 3 & 75.52 & 66.00 & 389 & $\begin{array}{l}5.09 \\
5.99\end{array}$ & 15.06 & 6.12 & 1.89 & 0.75 \\
\hline Ship & $863 \mathrm{~A}$ & $17 \mathrm{X}$ & CC & 153.34 & 62.44 & 4.94 & 6.86 & 15.75 & 6.78 & 1.70 & 0.86 \\
\hline Ship & $863 \mathrm{~A}$ & $18 \hat{x}$ & $\mathrm{CC}$ & 162.66 & 63.95 & 4.97 & 6.26 & 15.27 & 6.50 & 1.65 & 0.81 \\
\hline Shore & $863 \mathrm{~A}$ & $21 \mathrm{X}$ & 1 & 191.59 & 62.08 & 3.58 & 6.14 & 15.07 & 6.25 & 2.09 & 0.88 \\
\hline Ship & $863 \mathrm{~A}$ & $24 \mathrm{X}$ & $\mathrm{CC}$ & 221.01 & 62.30 & 4.20 & 6.64 & 16.48 & 6.42 & 2.48 & 0.79 \\
\hline Shore & $863 \mathrm{~A}$ & $25 \hat{\mathrm{X}}$ & 1 & 230.18 & 57.99 & 6.83 & $\begin{array}{l}5.04 \\
5.74\end{array}$ & 13.81 & 5.85 & 1.72 & 0.80 \\
\hline Ship & $863 \mathrm{~A}$ & $28 \mathrm{x}$ & i & 259.37 & 64.55 & 4.65 & 6.07 & 15.46 & 6.26 & 1.90 & 0.73 \\
\hline Ship & $863 \mathrm{~B}$ & $4 X$ & 3 & 329.55 & 58.36 & 5.24 & 6.12 & 14.65 & 10.26 & 1.58 & 0.75 \\
\hline Shore & $863 \mathrm{~B}$ & $4 \mathrm{X}$ & 3 & 329.72 & 62.75 & 5.13 & 6.11 & 14.29 & 6.24 & 1.51 & 0.84 \\
\hline Shore & $863 \mathrm{~B}$ & $7 \mathrm{~N}$ & 2 & 356.51 & 58.53 & 5.54 & 6.50 & 14.51 & 6.86 & 1.62 & 0.90 \\
\hline Ship & $863 \mathrm{~B}$ & $9 \mathrm{X}$ & $\overline{\mathrm{CC}}$ & 361.64 & 60.08 & 5.93 & 7.25 & 16.40 & 11.13 & 1.93 & 0.82 \\
\hline Shore & $863 \mathrm{~B}$ & $10 R$ & 1 & 371.00 & 58.22 & 5.83 & 6.14 & 13.97 & 6.61 & 1.59 & 0.87 \\
\hline Ship & $863 \mathrm{~B}$ & $12 \mathrm{R}$ & i & 386.47 & 60.69 & 5.23 & 7.16 & 16.37 & 11.02 & 1.92 & 0.84 \\
\hline Shore & $863 \mathrm{~B}$ & $17 \mathrm{R}$ & 5 & 441.64 & 58.77 & 4.63 & 6.04 & 13.97 & 6.42 & 1.69 & 0.85 \\
\hline Ship & $863 \mathrm{~B}$ & $23 R$ & $i$ & 493.36 & 61.78 & 4.76 & 7.03 & 16.21 & 11.14 & 1.61 & 0.85 \\
\hline Shore & $863 \mathrm{~B}$ & $26 R$ & 2 & 522.93 & 62.58 & 4.91 & 5.33 & 13.44 & 5.85 & 1.57 & 0.76 \\
\hline Shore & $863 \mathrm{~B}$ & $3 \mid \mathrm{R}$ & 2 & 570.94 & 56.86 & 8.02 & 5.29 & 13.02 & 5.58 & 1.54 & 0.78 \\
\hline Shore & $86.3 \mathrm{~B}$ & $49 \mathrm{R}$ & 4 & 738.70 & 59.05 & 5.54 & 5.68 & 13.14 & 5.75 & 1.48 & 0.79 \\
\hline
\end{tabular}

Note: The shore-based analyses were done by Amane Waseda. $\mathrm{MgO}^{*}$ represents the combination of $\mathrm{MgO}+\mathrm{Na}_{2} \mathrm{O}+$ $\mathrm{MnO}$

\section{Site 863}

The processed natural gamma-ray curves for Hole 863B are displayed in Figure 5. The through-pipe logs were not corrected, and the spikes seen in the upper $110 \mathrm{~m}$ of data are due to pipe joints, not lithologic changes. Open-hole logs begin at 231 mbsf. Processed geochemical logs for Hole 869B are displayed in Figure 6. Attempts have been made to correct for through-pipe conditions in the upper $200 \mathrm{~m}$ of the hole.

The sediments at Site 863 are composed of clayey silt and sandstones, reflecting a coarser (than Site 859) detrital origin from the nearby continental source. The sandstones below $240 \mathrm{mbsf}$ are vertically tilted and cemented sandstone (distal turbidite) unit. Both the core data and the logging data are thus effectively along-bedding profiles below 240 mbsf. The logging data and XRF data (listed in Table 3) are compositionally homogeneous, reflecting both the detrital source of the material and the along-bedding attitude of the profiles.

The logging and XRF major oxide data from Hole 863B show no evidence of the hydrothermal (metasomatic) mineralization (carbonate, zeolite, and pyrite cements and veins) observed in the cores below about 400 mbsf (Shipboard Scientific Party, 1992b). Mineralization in the basal portion of Site 863 was likely initiated upon collision of the toe of the accretionary prism with the subducting ridge axis, which occurred only about 50,000 years ago. Thus insufficient time has elapsed to render a measurable effect on the bulk composition of the rocks, although the mineralized veins and crystals are clearly visible in the cores themselves.

\section{ACKNOWLEDGMENT}

We thank MaryAnn Cusimano for providing shipboard XRF data.

\section{REFERENCES}

Grau, J.A., and Schweitzer, J.S., 1989. Elemental concentrations from thermal neutron capture gamma-ray spectra in geological formations. Nucl. Geophys., 3:1-9.
Grau, J.A., Schweitzer, J.S., and Hertzog, R.C., 1990. Statistical uncertainties of elemental concentrations extracted from neutron induced gamma-ray measurements. IEEE Trans. Nucl. Sci., 37:2175-2178.

Hertzog, R., Colson, L., Seeman, B., O'Brien, M., Scott, H., McKeon, D., Wraight, J., Grau, J., Ellis, D., Schweitzer, J., and Herron, M., 1989. Geochemical logging with spectrometry tools. SPE Form. Eval., 4:153162 .

Lock, G.A., and Hoyer, W.A., 1971. Natural gamma-ray spectral logging. Log Analyst, 12:3-9.

Pratson, E.L., Broglia, C., and Jarrard, R., 1993. Data report: geochemical well logs through Cenozoic and Quaternary sediments from Sites 815, 817, 820, 822, and 823. In McKenzie, J.A., Davies, P.J., Palmer-Julson, A., et al., Proc. ODP, Sci. Results, 133: College Station, TX (Ocean Drilling Program), 795-817.

Ruckebusch, G., 1983. A Kalman filtering approach to natural gamma ray spectroscopy in well logging. IEEE Trans. Autom. Control, AC-28:372380.

Schweitzer, J.S., Grau, J.A., and Hertzog, R.C., 1988. Precision and accuracy of short-lived activation measurements for in situ geological analyses. $J$. Trace Microprobe Techn., 6:437-451.

Scott, H.D., and Smith, M.P., 1973. The aluminum activation log. Log Analyst, 14:3-12.

Shipboard Scientific Party, 1992a. Site 859. In Behrmann, J.H., Lewis, S.D., Musgrave, R.J., et al., Proc. ODP, Init. Repts., 141: College Station, TX (Ocean Drilling Program), 75-157.

, 1992b. Site 863. In Behrmann, J.H., Lewis, S.D., Musgrave, R.J., et al., Proc. ODP, Init. Repts., 141: College Station, TX (Ocean Drilling Program), 343-446.

Abbreviations for names of organizations and publications in ODP reference lists follow the style given in Chemical Abstracts Service Source Index (published by American Chemical Society).

Date of initial receipt: 26 July 1993

Date of acceptance: 5 November 1993

Ms 141SR-032 


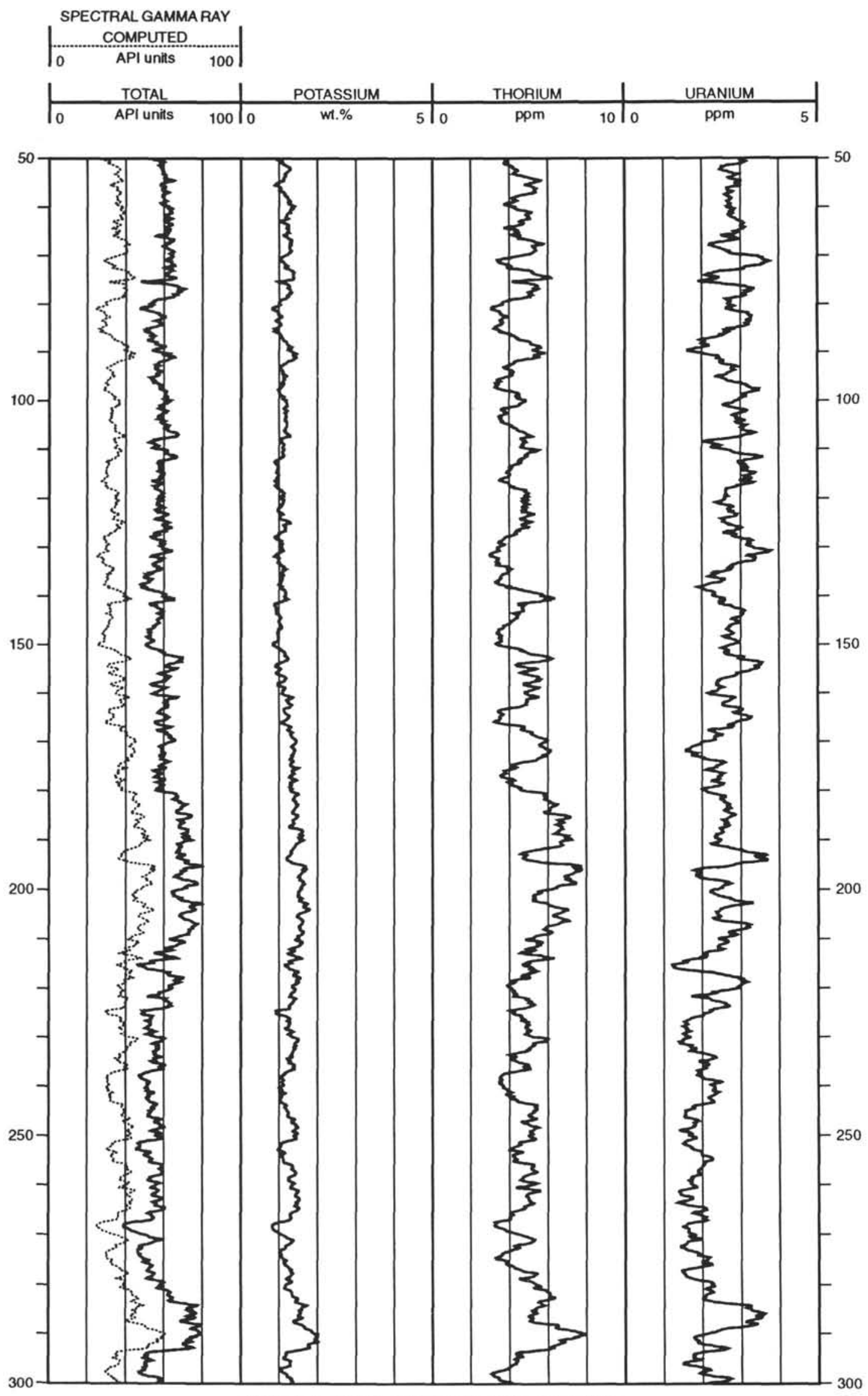

Figure 3. Processed natural gamma-ray data, Hole 859B. 

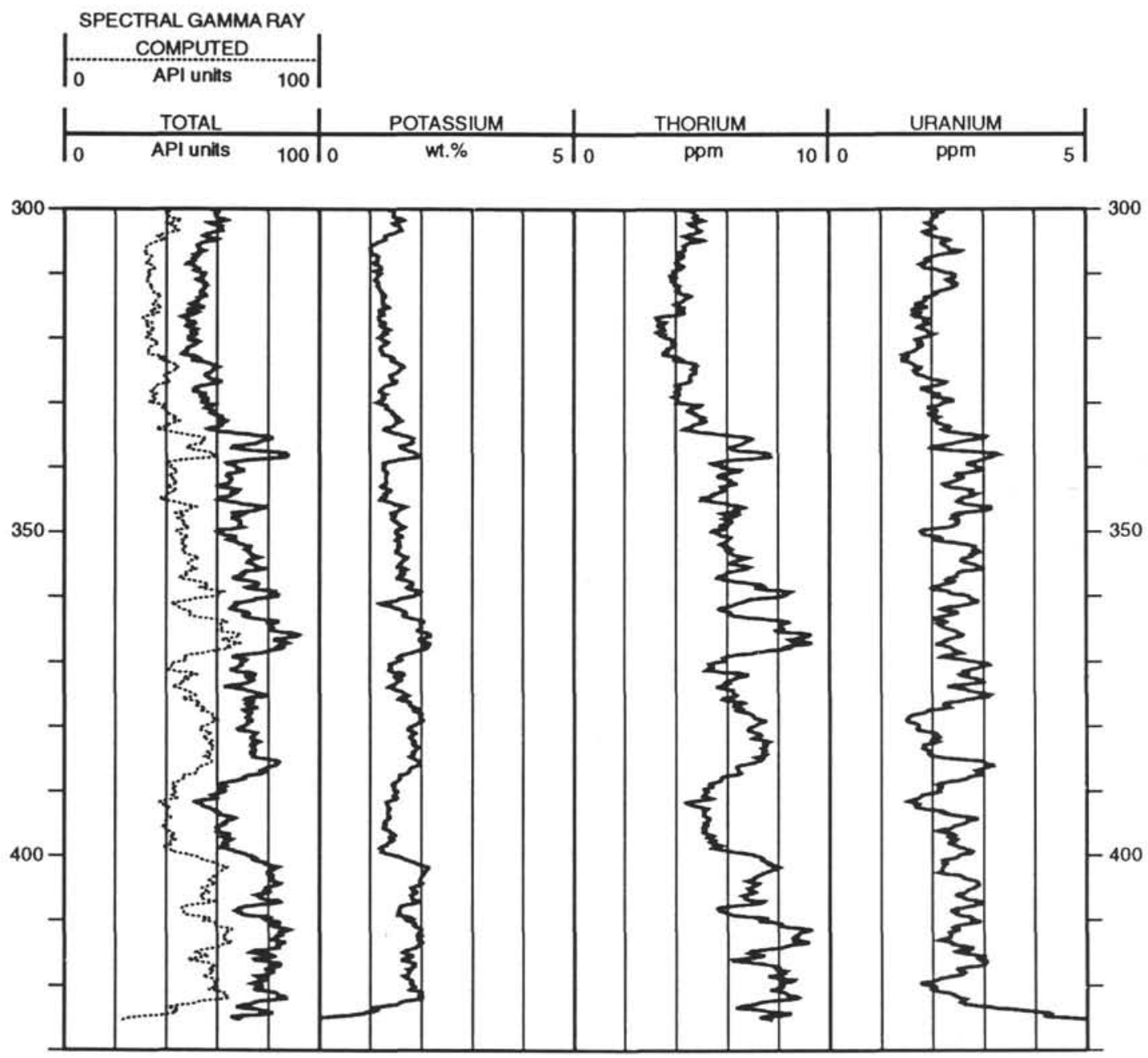

Figure 3 (continued). 


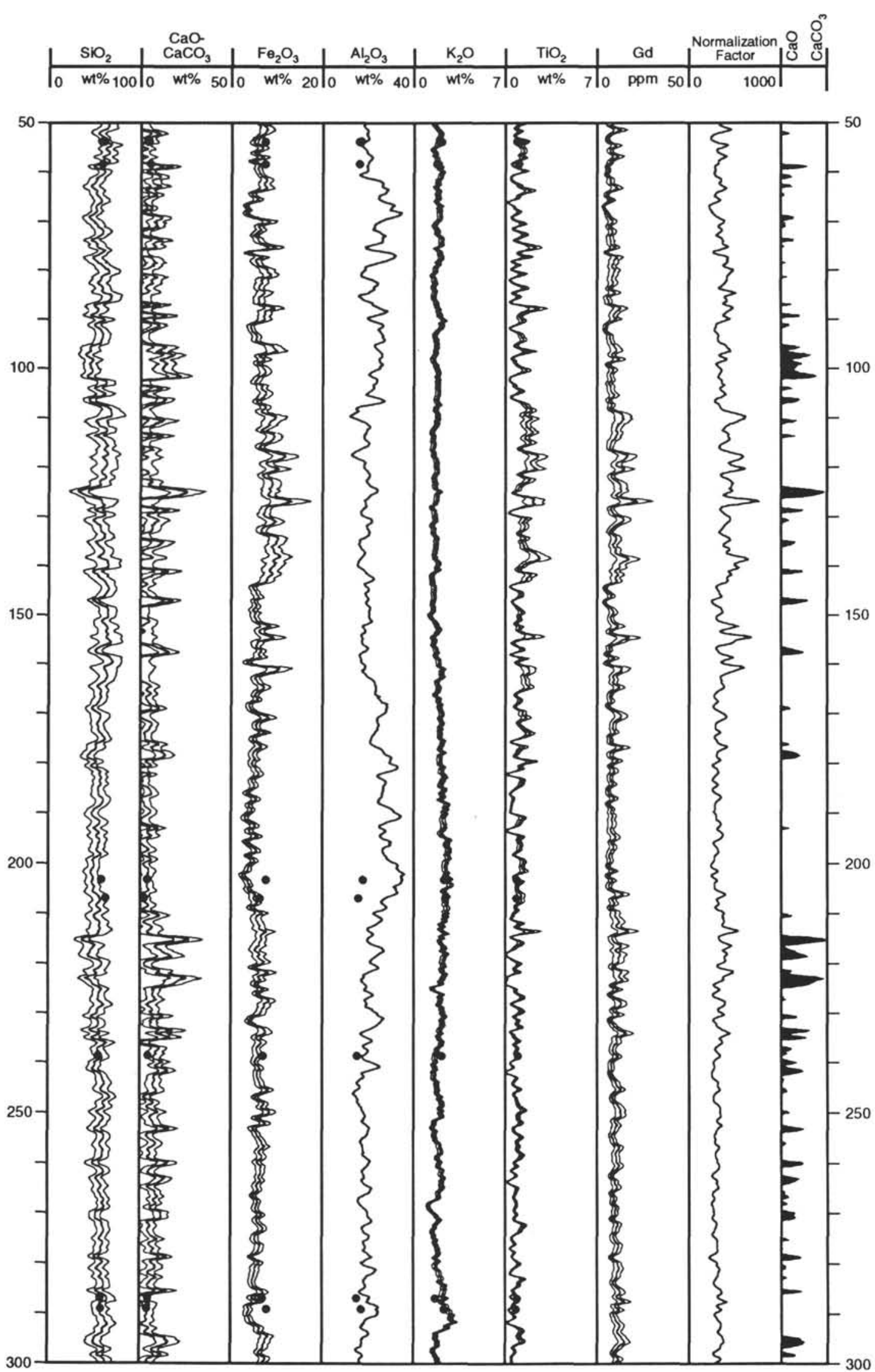

Figure 4. Estimates of major oxide-weight fractions from geochemical logs, Hole 859B. Solid circles represent XRF measurements (Shipboard Scientific Party, 1992a). 


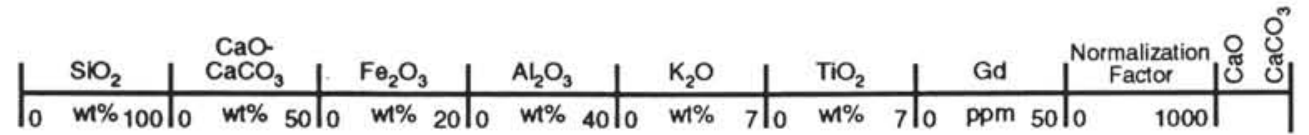

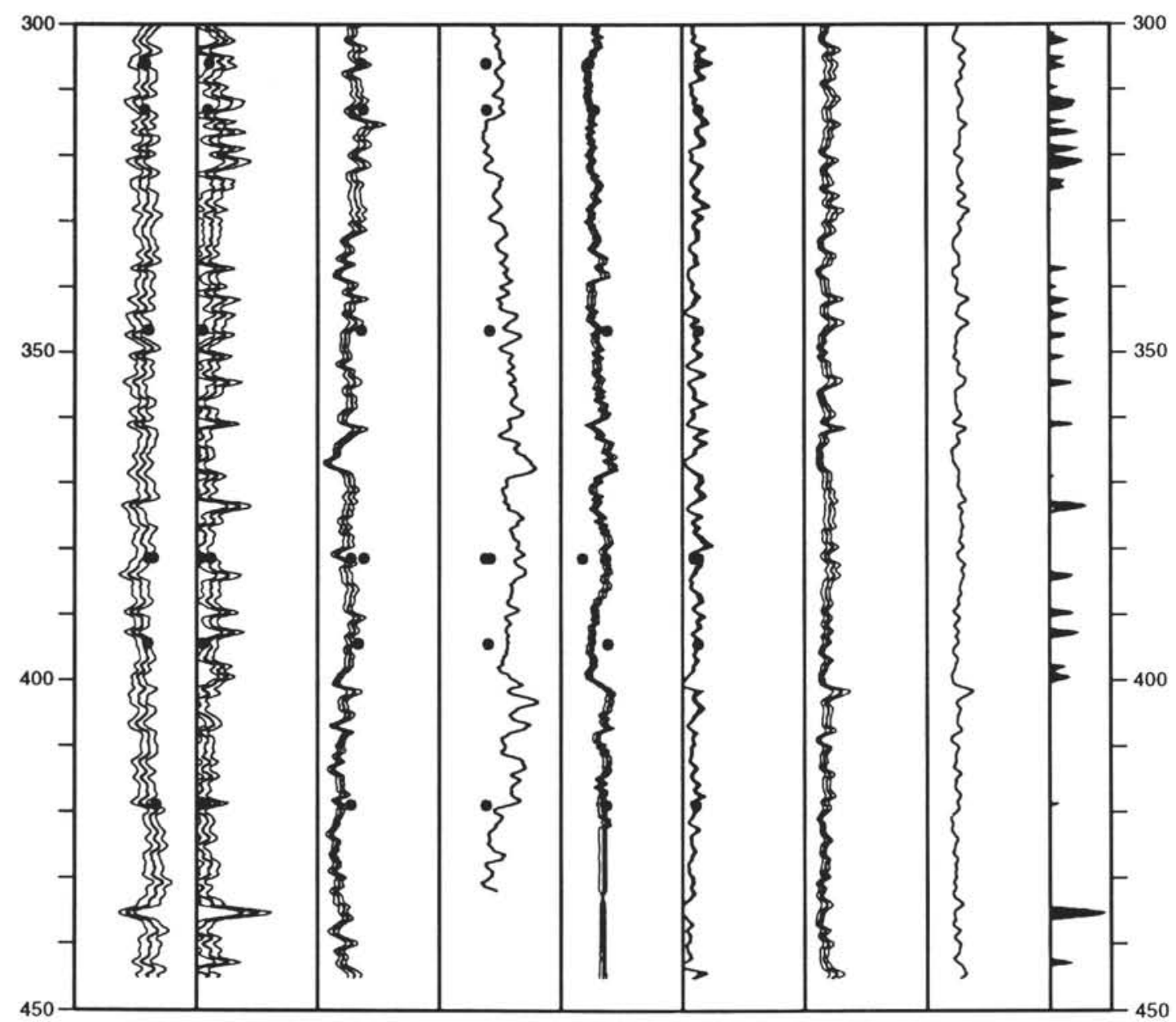

Figure 4 (continued). 

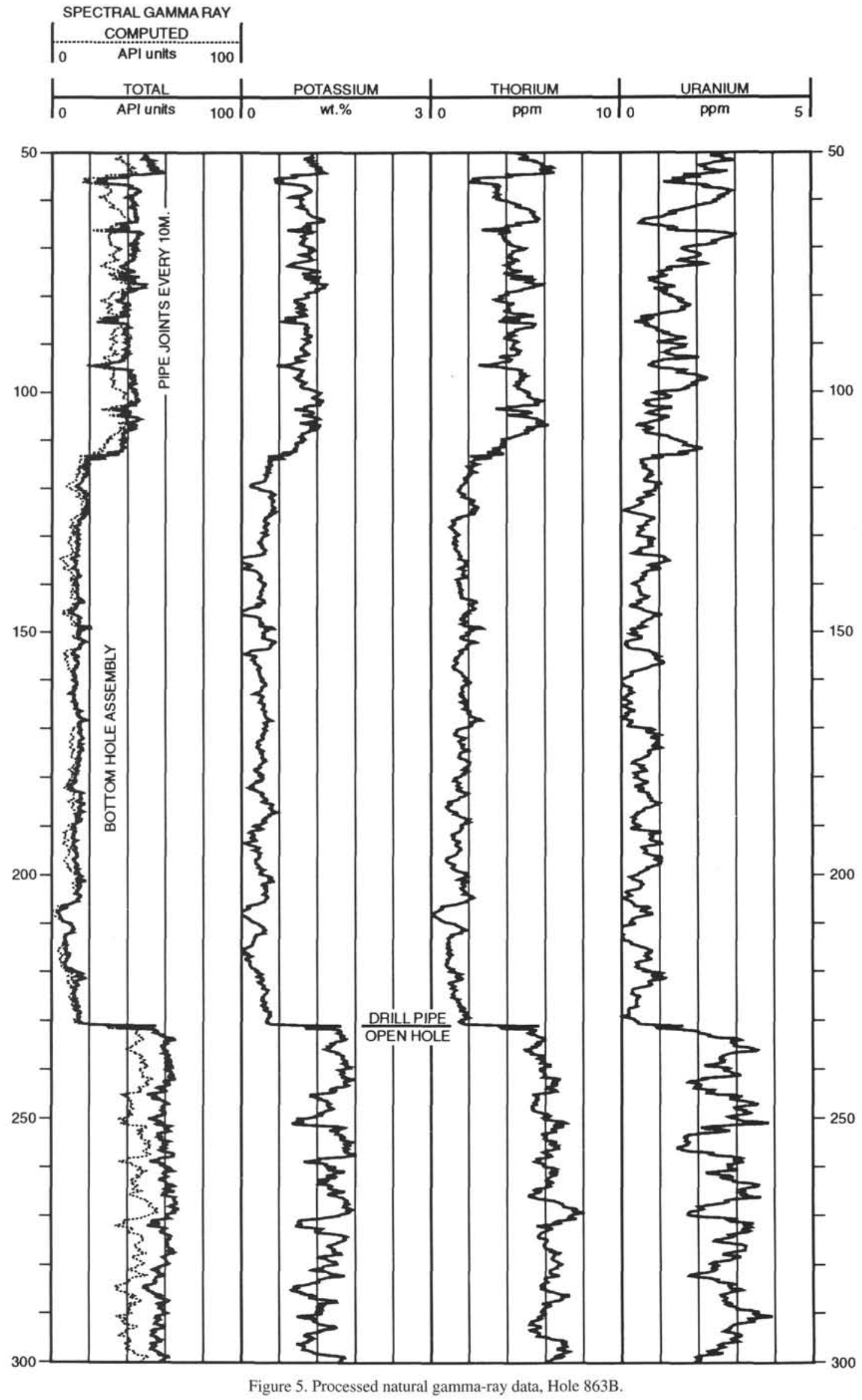


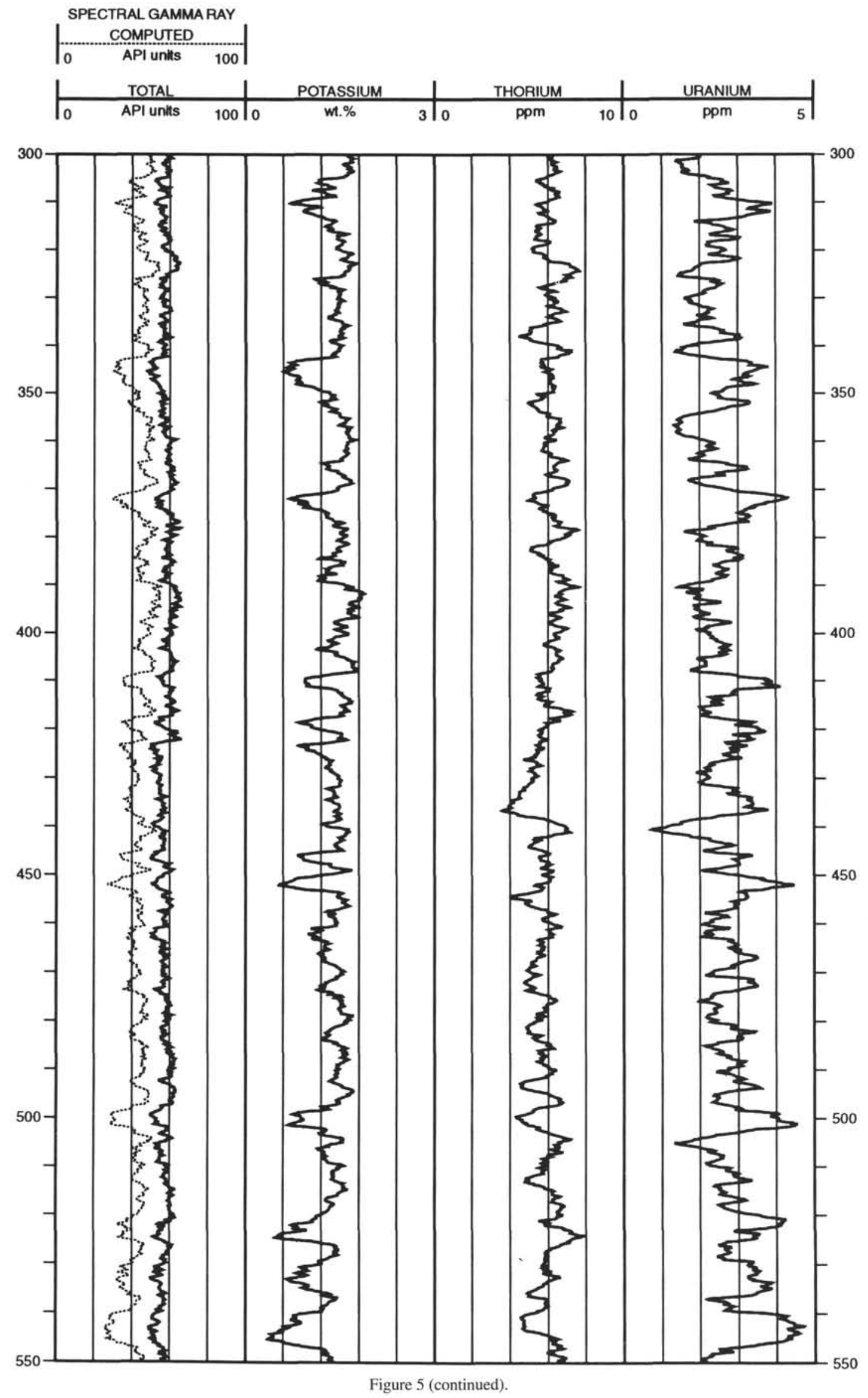




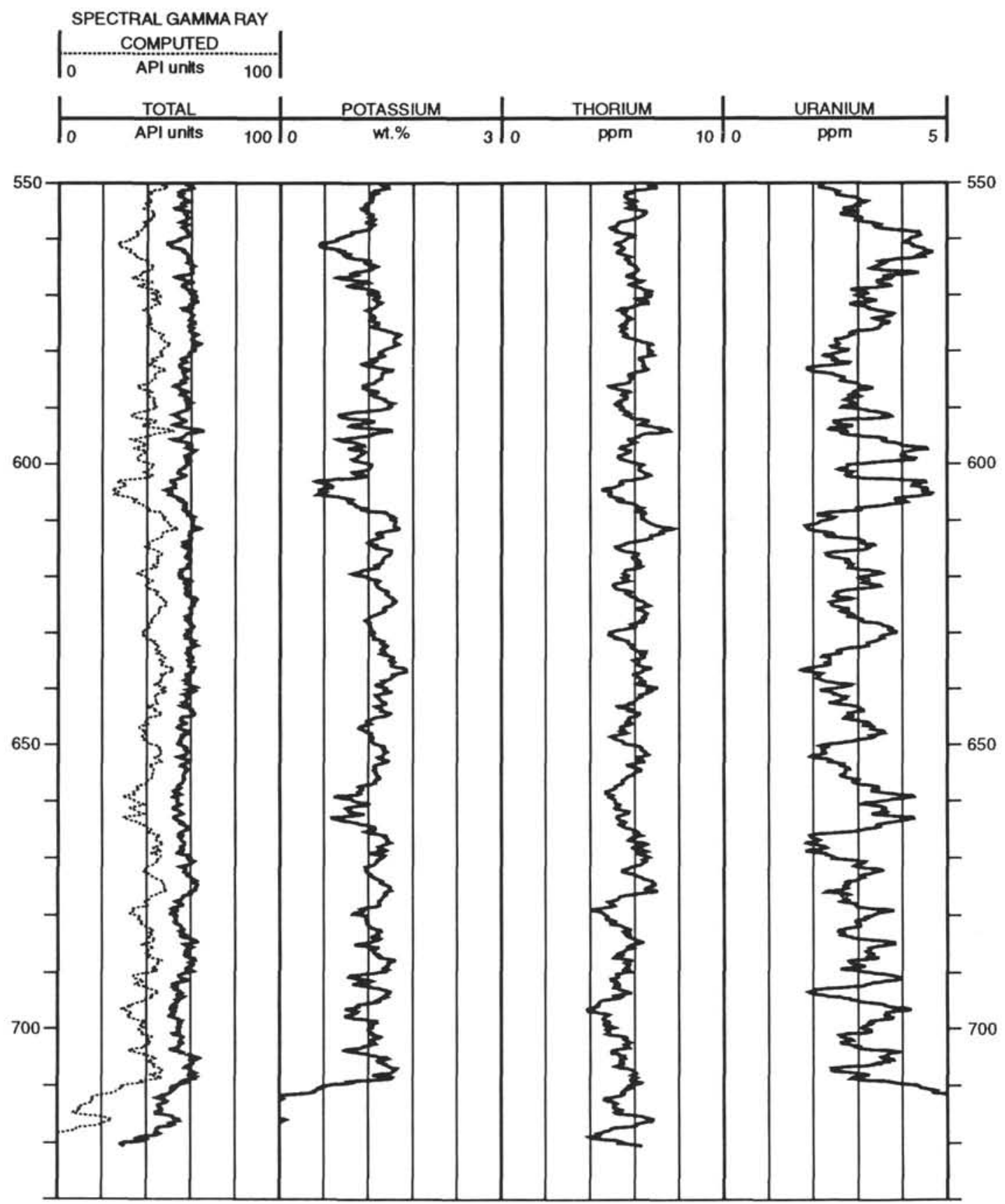

Figure 5 (continued). 


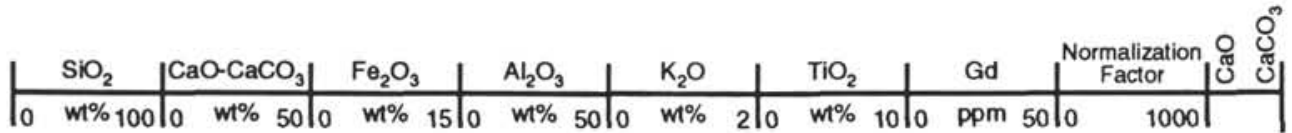

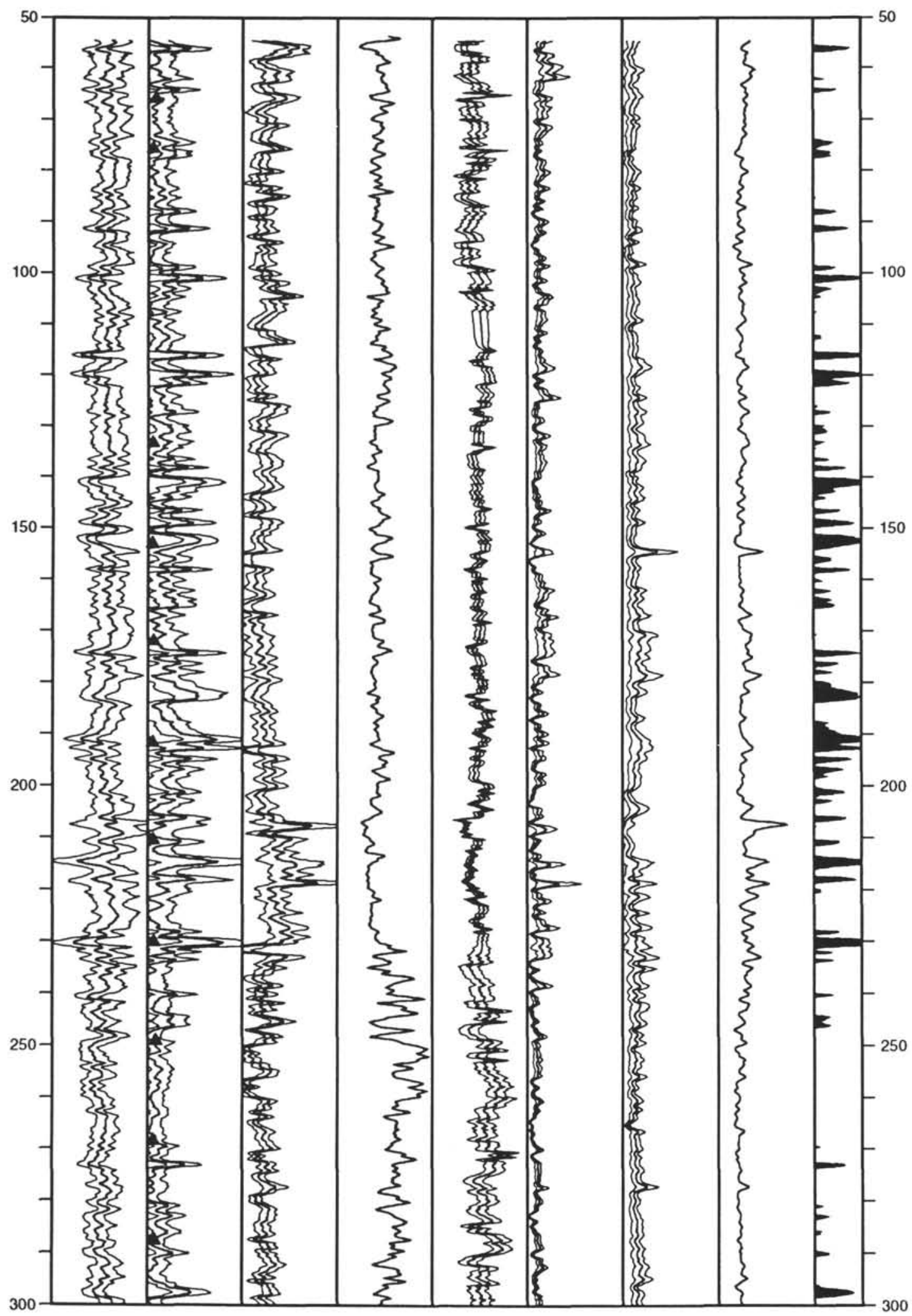

Figure 6. Estimates of major oxide-weight fractions from geochemical logs, Hole 863B. Solid circles represent XRF measurements, triangles represent carbonate bomb measurements from core (Shipboard Scientific Party, 1992b). 


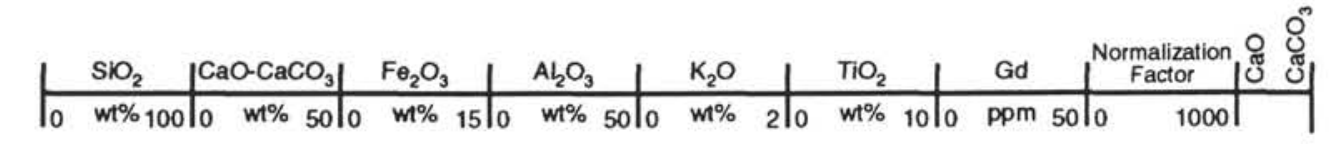

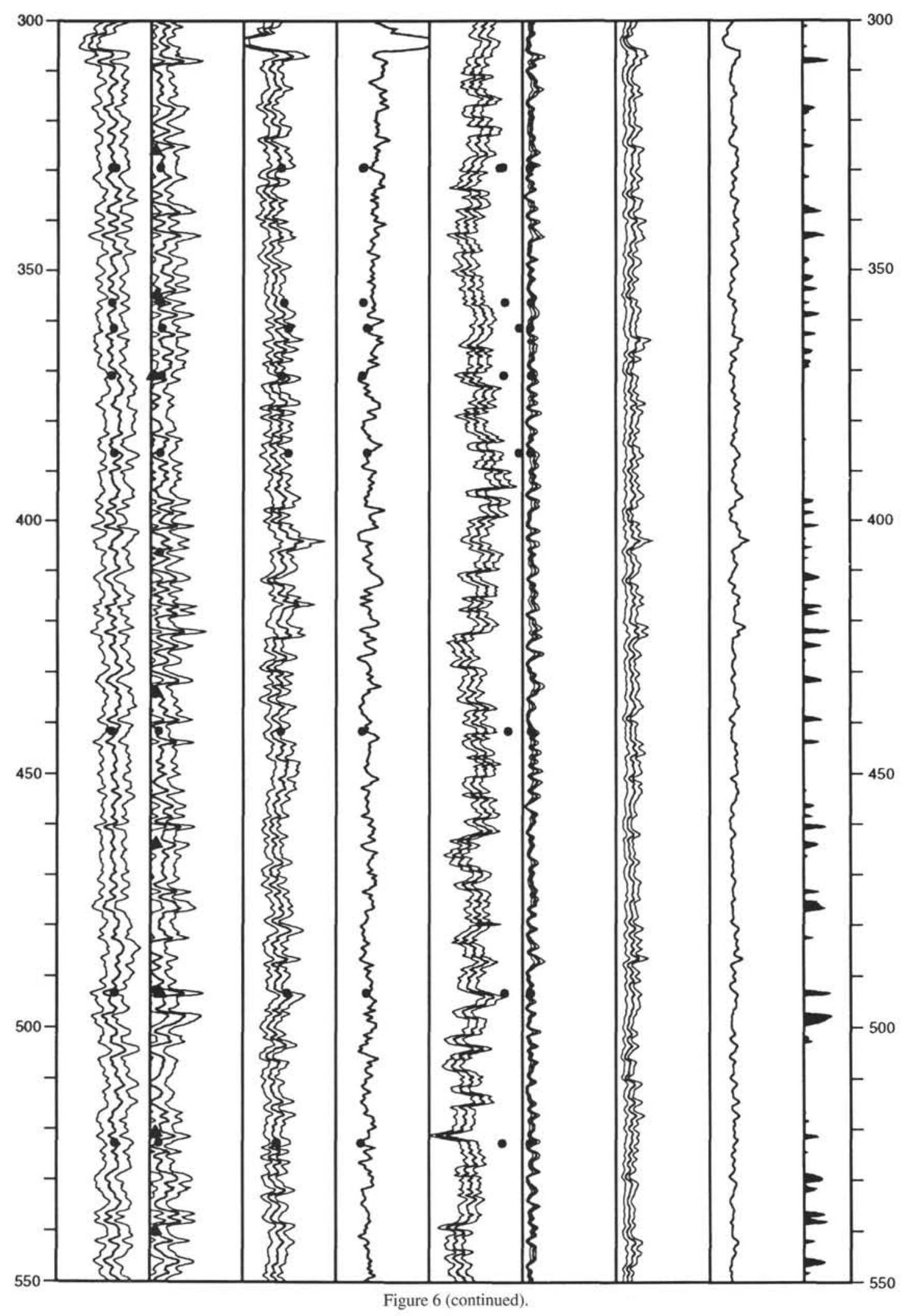




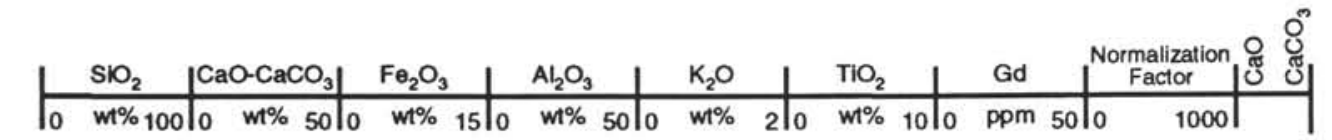

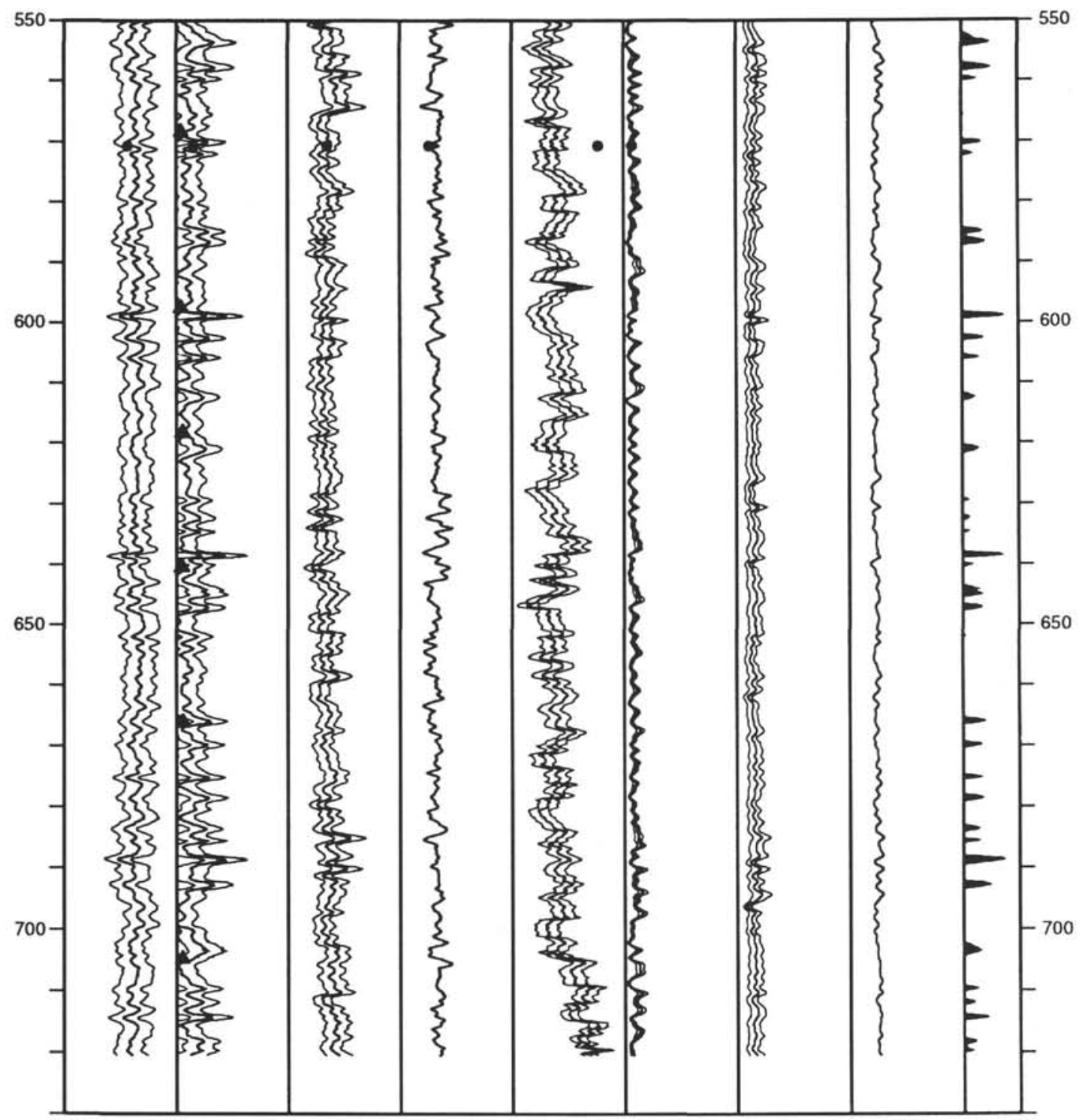

Figure 6 (continued). 